\title{
NEW APPLICATION OF MICROBIAL L-GLUTAMINASE AS A FLAVOR ENHANCING AGENT IN BEEF BURGERS
}

Reda M. Mohamed, Wael A. Bazaraa*, Ahmed M. Alian, Nagwa M. EL-Shimi Cairo University, Faculty of Agriculture, Giza, Egypt

\begin{abstract}
Keywords: microbial L-glutaminase, beef burger, sensory evaluation, monosodium glutamate, flavor enhancer
Abstract

L-glutaminase (L-glutamine amidohydrolase EC3.5.1.2) is the key enzyme in enhancing the taste and aroma of oriental fermented foods by increasing their glutamic acid content and as a result imparting a palatable taste. Beef burgers were prepared using different levels of the partially purified L- glutaminase (2.0 to10.0 U/100 g) prepared from Aspergillus oryzae NRRL 32567. Beef burgers treated with $6.0 \mathrm{U} / 100 \mathrm{~g}$ and the others treated with monosodium glutamate (5000 ppm) were chemically, sensory and microbiologically evaluated and compared to untreated control during frozen storage at $-18^{\circ} \mathrm{C}$ for 3 months. Treatment with L-glutaminase $(6 \mathrm{U} / 100 \mathrm{~g})$ resulted in an increase of $443 \%$ in glutamic acid and a reduction of $63 \%$ in glutamine contents resulting in an enhanced preferable taste and odor of the prepared beef burgers. Burgers treated with $6.0 \mathrm{U} / 100 \mathrm{~g}$ exhibited the best odor, texture, taste and overall quality scores when compared to the untreated control and samples treated with monosodium glutamate (5000 ppm). During the frozen storage of all samples, an expected slight, but significant ( $p \leq 0.05)$, increase in the total mesophilic bacterial count was evident and such increase was quite acceptable since numbers did not exceed the limit of $5.7 \times 10^{3} \mathrm{cfu} / \mathrm{g}$. Similarly, the total psychrotrophs did not exceed $3.7 \times 10^{2} \mathrm{cfu} / \mathrm{g}$.
\end{abstract}

For citation: Mohamed, R.M., Bazaraa, W.A., Alian, A.M., El-Shimi, N.M. (2021). New application of microbial l-glutaminase as a flavor enhancing agent in beef burgers. Theory and practice of meat processing, 6(4), 375-380. https://doi.org/10.21323/2414438X-2021-6-4-375-380

\section{Introduction}

L-Glutaminase (L-glutamine amidohydrolase EC3.5.1.2) catalyzes the hydrolysis of L-glutamine to L-glutamic acid and ammonia [1,2]. L-glutaminase is generally regarded as a key enzyme in enhancing the taste and aroma of oriental fermented foods such as soy sauce by increasing their glutamic acid content and thereby imparting a palatable taste $[3,4,5]$. Amino acids that are produced by the enzymatic degradation of the proteins contained in the raw materials are well known as basic flavor components of fermented condiments. L-glutamic acid is one such flavor enhancing amino acid produced by the hydrolytic action of L-glutaminase on L-glutamine [6,7].

Monosodium glutamate (MSG) gives the taste "umami", which has been widely recognized as the fifth basic taste besides sweet, acid, salty and bitter. It has been widely used as a flavor enhancer in the food industry. However, there is some questions about its safety, since it may cause some side effects for some people such as wheezing, changes in the heart rate and difficulty in breathing $[8,9]$. Therefore, the need to develop a safer natural flavor enhancer as an alternative to MSG has been increased.

Glutamic and aspartic acids are well known amino acids contributing not only fine taste, "umami" and sharp sour taste but also nutritional effects to food $[10,11]$. Therefore, in the present study, microbial L-glutaminase has replaced the use of monosodium glutamate to enhance flavor in beef burgers. Besides, the effect of such replacement on the chemical, sensory and microbiological quality of the produced burger were evaluated.

\section{Materials and methods}

\section{Enzyme}

Partially purified Aspergillus oryzae NRRL 32567 L-glutaminase was utilized in this study $[12,13]$.

\section{Raw materials}

Frozen lean beef and fat were purchased from the local market in Giza, Egypt. Soy flour was obtained from Food Technology Research Institute, Agricultural Research Center, Giza, Egypt.

\section{Formulation of beef burgers}

Beef burgers were prepared, in accordance with the Egyptian standard specification for beef burgers (ES: 1688-2005) [14], as follows: $60 \%$ frozen lean beef, $20 \%$ fat, $10 \%$ soy flour, $1.3 \%$ spices mixture, $1.7 \%$ salt, $1 \%$ corn starch, $1 \%$ casein and 5\% onion. All ingredients were well mixed and then the mixture was divided into two batches. The first batch was divided into six treatments (a control and five treatments with partially purified L-glutaminase at different concentrations, from 2.0 to $10.0 \mathrm{U} / 100 \mathrm{~g}$ ). Each treatment was separately mixed for 5 min at medium speed to obtain homogeneous mixture. This mixture was shaped using a commercial burger maker to obtain burgers of approximately $9 \mathrm{~cm}$ diameter, $50 \mathrm{~g}$ in weight and $0.5 \mathrm{~cm}$ thick. Burgers were then cooked by frying in 
sunflower oil and evaluated by sensory analysis. The second batch was divided into three portions; the first was used as control, the second (treatment A) was mixed with $5000 \mathrm{ppm}$ of monosodium glutamate, while, the third batch (treatment B) was mixed with $6.0 \mathrm{U} / 100 \mathrm{~g}$ of the partially purified glutaminase (as the best enzyme concentration). Each treatment was processed as described before to obtain beef burgers that were packed in foam plates and stored at $-18{ }^{\circ} \mathrm{C}$ for 3 months. After storing, samples from the three treatments were chemically and microbiologically evaluated (after thawing) every month. Sensory evaluation was performed on the cooked burgers only at the end of storage.

\section{Enzyme assay}

The glutaminase activity was assayed according to Imada et al. [15]. One unit of glutaminase was defined as the amount of enzyme that liberates $1 \mu \mathrm{mol}$ of ammonia under optimal assay conditions.

\section{Chemical analyses}

Moisture, protein, fat, crude fibers, total ash and total carbohydrates of beef burger samples were determined according to the official methods [16]. Free amino acids (FAA) were analyzed by HPLC [17]. The $\mathrm{pH}$ value of beef burger samples was measured by homogenizing $10 \mathrm{~g}$ of sample with $100 \mathrm{ml}$ distilled water for $30 \mathrm{sec}$. The $\mathrm{pH}$ of the prepared sample was measured using a $\mathrm{pH}$ meter (Orion $301, \mathrm{USA})$ at $20^{\circ} \mathrm{C}$ [18].

\section{Microbiological quality}

Samples $(30 \mathrm{~g})$ were aseptically taken from each beef burger and homogenized with peptone water $(0.1 \%)$ in a Lab-Blender for $3 \mathrm{~min}$ to have a final dilution of 1:10. Serial decimal dilutions were made using the same diluent and then plated in duplicate for bacterial counts. Aerobic mesophilic bacteria were determined on plate count agar (Merck, Darmstadt, Germany) after $48 \mathrm{~h}$ incubation at $30^{\circ} \mathrm{C}$. Mold and yeast were counted on acidified potato dextrose agar (Merck, Darmstadt, Germany) after $48 \mathrm{~h}$ incubation period at $28^{\circ} \mathrm{C}$. Coliform group was determined on MacConkey agar (Merck, Darmstadt, Germany) after $48 \mathrm{~h}$ incubation at $37^{\circ} \mathrm{C}$. Psychrotrophs were determined on plate count agar (Merck, Darmstadt, Germany) after ten-day incubation at $7^{\circ} \mathrm{C}[19]$.

\section{Sensory evaluation}

Burgers were assessed for a number of sensory characteristics by ten members from the Food Science Department, Faculty of Agriculture, Cairo University, Egypt. They were selected on the basis of interest and experience in sensory evaluation and availability. Panelists were instructed to evaluate color, texture, taste, odor and overall quality using 10-point hedonic scale for grading the quality of samples where, 10 points indicated the highest acceptability and 5 was the acceptance boundary. On the other hand, 4 points indicated unacceptable samples [20].

\section{Statistical analysis}

Results were subjected to one way analysis of variance, ANOVA [21], and data were presented as the mean of three experiments.

\section{Results and discussion}

\section{Chemical composition of frozen beef}

The chemical composition of the frozen beef meat was as follows ( $\mathrm{g} / 100 \mathrm{~g}$ fresh weight): 75.0 , moisture; 18.5, protein; 5.56, fat; 1.0, ash and zero total carbohydrates. These results were in accordance with those of Gehan and Emara [22] and Kassem et al. [23].

\section{Chemical composition of frozen beef burgers}

The moisture content of prepared beef burgers at zero time was $62.51,62.49$ and $63 \%$ for control, treatment $A$ and treatment $B$ samples, respectively. A slight reduction in the moisture content during burger frozen storage was expected and it was due to the evaporation of moisture through the polyethylene bags $[24,25]$. The protein content was 15.2, 15.18 and $15.5 \%$ for the control, treatment $\mathrm{A}$ and treatment B samples, respectively at zero time. A very slight decrease in the protein content during frozen storage at $-18^{\circ} \mathrm{C}$ was noted and might be a result of slight protein degradation by meat enzymes [26]. Also, at zero time, the fat content was $16.72,16.70$ and $16.3 \%$, ash content was $1.73,1.75$ and $1.77 \%$, crude fibers content was $1.26,1.33$ and $1.00 \%$ and carbohydrate content was $2.58,2.55$ and $2.45 \%$ for the control, treatment $\mathrm{A}$ and treatment $\mathrm{B}$ samples, respectively. On the other hand, during storage at $-18^{\circ} \mathrm{C}$, storage such values were slightly increased for all samples due to a decrease in the moisture content $[25,27,28]$. The hydrolysis of meat proteins generates polypeptides that can be further degraded to smaller peptides and free amino acids. This degradation can be produced by endogenous and microbial enzymes as reported by different authors [29,30,31]. The results for free amino acids generated during beef burger processing of both the control and treatment B are presented in Table 1. Mainly, results clearly show an increase in the amount of glutamic acid from 23 to $125 \mathrm{mg} / 100 \mathrm{~g}$ and a decrease in glutamine content from 119 to $75 \mathrm{mg} / 100 \mathrm{~g}$ in the control and treatment B samples, respectively. These results were the direct effect of the added L-glutaminase. Such findings were confirmed when both odor and taste scores increased by the addition of L-glutaminase up to $6.0 \mathrm{U} / 100 \mathrm{~g}$ (Table 2). It was reported that the large amounts of hydrophobic amino acids (such as methionine, valine, leucine and tryptophan, which are usually associated with bitter taste) were generated during processing $[32,33]$. Some of these amino acids, especially the branched-chain amino acids, have been proved to be metabolized by Debaryomyces sp. generating volatile compounds in dry fermented sausage [34]. Meanwhile, high quantities of alanine and glutamic acid caused a sweet taste and umami sensation, respectively, the final sausages [35]. Therefore, the balance of these free amino acids will affect the sensory characteristics of the product [36,37]. 
Table 1. Free amino acid (FAA, mg per $100 \mathrm{~g}$ dry matter) concentration in beef burgers at zero time

\begin{tabular}{|l|c|c|}
\hline \multicolumn{1}{|c|}{ FAA } & Control & Treatment B \\
\hline Asparagine & 3.4 & 3.9 \\
\hline Glutamic acid & 23.0 & 125.0 \\
\hline Serine & 8.3 & 9.2 \\
\hline Glycine & 20.6 & 25.0 \\
\hline Glutamine & 119.0 & 72.0 \\
\hline Alanine & 58.0 & 61.0 \\
\hline Arginine & 7.1 & 7.4 \\
\hline Proline & 8.2 & 9.4 \\
\hline Tyrosine & 5.3 & 10.0 \\
\hline Histidine & 4.2 & 6.1 \\
\hline Threonine & 6.7 & 8.2 \\
\hline Valine & 8.5 & 10.0 \\
\hline Methionine & 3.4 & 9.2 \\
\hline Tryptophan & 2.1 & 4.1 \\
\hline Leucine & 9.0 & 13.0 \\
\hline
\end{tabular}

\section{Sensory evaluation of beef burgers as affected by}

different levels of partially purified glutaminase

Beef burgers were prepared using different levels of partially purified glutaminase ( 2.0 to $10.0 \mathrm{U} / 100 \mathrm{~g}$ ) and data are presented in Table 2. Results indicate that, odor scores ranged from 6.5 to 9.0 and the best odor was observed for the sample with enzyme treatment of $6.0 \mathrm{U} / 100 \mathrm{~g}$. Meanwhile, increasing the enzyme concentration above 6.0 units caused a gradual decrease in the odor attribute. Increasing the enzyme concentration, up to $8.0 \mathrm{U} / 100 \mathrm{~g}$, in burger treatments caused an increase in texture scores. This increase in texture scores may be due to the increase in the proteases content contaminating the partially purified glutaminase. These proteases improved tenderness of beef burgers as compared with the control sample. Regarding taste, it was noticed that by increasing the glutaminase level, the taste scores increased reaching the highest level of 9.0 for samples treated with $6.0 \mathrm{U} / 100 \mathrm{~g}$ followed by a gradual decrease where scores of 7.5 and 6.0 were obtained for samples treated with 8.0 and $10.0 \mathrm{U} / 100 \mathrm{~g}$, respectively. Such decrease in scores was due to the appearance of bitter taste (as distinguished by panelists) which was probably due to the degradation of protein and an increase in the bitter amino acids such as: methionine, valine, leucine and tryptophan [32]. The highest color score (8.8) was recorded for the control sample. By increasing the enzyme level, the color attribute decreased due to the increase in the undesirable dark color, which was probably due to the formation of the Maillard reaction between reducing sugars and the formed amino acids and the lowest score (6.0) obtained at $10.0 \mathrm{U} / 100 \mathrm{~g}$. Also, the highest overall quality score of 8.6 was given by the panelists for the sample treated with $6.0 \mathrm{U} / 100 \mathrm{~g}$ followed by the score of 8.0 for the sample treated with $4.0 \mathrm{U} / 100 \mathrm{~g}$. Therefore, the concentration of $6.0 \mathrm{U} / 100 \mathrm{~g}$ was selected as the best enzyme concentration and was used for the further experiments.

Data in Table 3 indicate that the $\mathrm{pH}$ values of different beef burgers (control, treatment $\mathrm{A}$ and treatment $\mathrm{B}$ ) at zero time ranged from 6.15 to 6.60 with significant differences (5\% level) between them. Similarly, the $\mathrm{pH}$ values of all samples during storage showed significant differences $(\mathrm{p} \leq 0.05)$. A slight but significant decrease in $\mathrm{pH}$ values for all samples was noted after one month of storage. This might be due to the breakdown of glycogen to lactic acid [24]. Then, $\mathrm{pH}$ values were stable until the end of storage.

Table 3. $\mathrm{pH}$ values of beef burgers during frozen storage at $-18^{\circ} \mathrm{C}$ for 3 months.

\begin{tabular}{|c|c|c|c|c|}
\hline \multirow{2}{*}{ Treatments } & \multicolumn{4}{|c|}{ Storage time (month) } \\
\hline & Zero & 1 & 2 & 3 \\
\hline${ }^{\star} \mathrm{C}$ & ${ }^{*} 6.15^{c}{ }_{a}$ & $6.05_{b}^{c}$ & $6.02^{\mathrm{c}}{ }_{\mathrm{b}}$ & $6.01_{b}^{\mathrm{c}}$ \\
\hline A & $6.25^{b}$ & $6.15^{b}$ & $6.12^{b}{ }_{b}$ & $6.11^{b}{ }_{b}^{b}$ \\
\hline B & $6.60^{\mathrm{a}}{ }_{\mathrm{a}}$ & $6.47^{\mathrm{a}}{ }_{\mathrm{b}}$ & $6.46^{\mathrm{a}}{ }_{\mathrm{b}}$ & $6.45^{\mathrm{a}}{ }_{\mathrm{b}}$ \\
\hline
\end{tabular}

${ }^{\star} \mathrm{C}=$ Control, $\mathrm{A}=$ treatment with monosodium glutamate at $5000 \mathrm{ppm}, \mathrm{B}=$ treatment with partially purified glutaminase $(6.0 \mathrm{U} / 100 \mathrm{~g})$

** Means followed by different superscripts (within each column) and different subscripts (within row) are significantly different $(\mathrm{p} \leq 0.05)$.

\section{Microbiological quality of beef burger}

The total bacterial count has been used to assess sanitary quality and safety of various meat products. High microbial load leads to certain undesirable changes in color, flavor and accumulation of their toxins in meat [38]. The results (Table 4) indicate that at zero time all samples including control were acceptable in terms of microbiological quality since the microbial load range was $3.1-3.3 \times 10^{3} \mathrm{cfu} / \mathrm{g}$, which was much lower than the limit $\left(10^{5} \mathrm{cfu} / \mathrm{g}\right)$ of the Egyptian Standard Specification (ES: 1688-2005) of frozen beef burgers [14]. It is essential to start with clean raw materials to get high quality products even over a period of long-term storage. During storage, an expected slight, but significant $(\mathrm{p} \leq 0.05)$, increase in the microbial count was evident and such increase was quite acceptable since numbers did not exceed the limit of $10^{3}$. This could be due

Table 2. Sensory evaluation of beef burgers as affected by different levels ( 2.0 to $10.0 \mathrm{U} / 100 \mathrm{~g})$ of partially purified glutaminase \pm SD

\begin{tabular}{|c|c|c|c|c|c|c|}
\hline \multirow{2}{*}{ Characteristic } & \multicolumn{6}{|c|}{ Treatments } \\
\hline & ${ }^{\star} \mathrm{C}$ & $2 \mathrm{U}$ & $4 \mathrm{U}$ & $6 \mathrm{U}$ & $8 \mathrm{U}$ & $10 \mathrm{U}$ \\
\hline Odor & $* * 7.0^{\mathrm{d}} \pm 0.00$ & $7.5^{\mathfrak{c}} \pm 0.01$ & $8.2^{b} \pm 0.03$ & $9.0^{a} \pm 0.00$ & $7.2^{\mathrm{d}} \pm 0.01$ & $6.5^{\mathrm{e}} \pm 0.01$ \\
\hline Color & $8.8^{a} \pm 0.02$ & $8.5^{b} \pm 0.00$ & $8.2^{c} \pm 0.01$ & $7.5^{\mathrm{d}} \pm 0.02$ & $7.0^{e} \pm 0.01$ & $6.0^{f} \pm 0.00$ \\
\hline Texture & $7.5^{\mathrm{d}} \pm 0.00$ & $8.0^{c} \pm 0.01$ & $8.5^{b} \pm 0.02$ & $8.9^{\mathrm{a}} \pm 0.00$ & $9.0^{a} \pm 0.00$ & $8.0^{c} \pm 0.02$ \\
\hline Taste & $6.5^{\mathrm{d}} \pm 0.01$ & $7.5^{c} \pm 0.01$ & $8.0^{b} \pm 0.00$ & $9.0^{a} \pm 0.01$ & $7.5^{c} \pm 0.02$ & $6.0^{e} \pm 0.01$ \\
\hline Overall quality & $7.0^{d} \pm 0.03$ & $7.7^{\mathfrak{c}} \pm 0.02$ & $8.2^{b} \pm 0.01$ & $8.6^{a} \pm 0.02$ & $7.7^{\mathfrak{c}} \pm 0.03$ & $6.1^{\mathrm{e}} \pm 0.00$ \\
\hline
\end{tabular}

${ }^{\star} \mathrm{C}=$ Control ${ }^{\star *}$ Means followed by different superscripts within each row are significantly different $(\mathrm{p} \leq 0.05)$. 
to an increase in the amounts of free nitrogen compounds as well as fatty acids due to the slow activity of proteases and lipases during storage, which allow for better microbial growth.

Microorganisms that can grow at refrigerated conditions have usually been called psychrotrophic microorganisms. They are a subgroup of mesophilic microorganisms and when presented in large numbers can cause a variety of off-flavors as well as physical damage to refrigerated food [39]. Psychrotrophic bacterial counts ( $\mathrm{cfu} / \mathrm{g}$ ) in beef burgers (treatment $\mathrm{A}$ and $\mathrm{B}$ as well as control) were monitored during storage at $-18^{\circ} \mathrm{C}$ for three months (Table 5).

Table 4. Total bacterial count (cfu/g) in beef burgers during frozen storage at $-18^{\circ} \mathrm{C}$ for 3 months.

\begin{tabular}{c|c|c|c|c|}
\multirow{2}{*}{ Treatments } & \multicolumn{4}{|c}{ Storage time (month) } \\
\cline { 2 - 5 } & Zero & 1 & 2 & 3 \\
\hline${ }^{\star} \mathrm{C}$ & $\star * 3.3 \times 10^{3 \mathrm{a}}{ }_{\mathrm{d}}$ & $3.9 \times 10^{3 \mathrm{a}}{ }_{\mathrm{c}}$ & $4.8 \times 10^{3 \mathrm{a}}{ }_{\mathrm{b}}$ & $5.7 \times 10^{3 \mathrm{a}}{ }_{\mathrm{a}}$ \\
\hline $\mathrm{A}$ & $3.0 \times 10^{3 \mathrm{a}}{ }_{\mathrm{bc}}$ & $3.2 \times 10^{3 \mathrm{~b}}{ }_{\mathrm{b}}$ & $3.6 \times 10^{3 \mathrm{c}}{ }_{\mathrm{b}}$ & $4.5 \times 10^{3 \mathrm{~b}}{ }_{\mathrm{a}}$ \\
\hline $\mathrm{B}$ & $3.1 \times 10^{3 \mathrm{a}}{ }_{\mathrm{d}}$ & $3.7 \times 10^{3 \mathrm{a}}{ }_{\mathrm{c}}$ & $4.2 \times 10^{3 \mathrm{~b}}{ }_{\mathrm{b}}$ & $5.7 \times 10^{3 \mathrm{a}}{ }_{\mathrm{a}}$ \\
\hline
\end{tabular}

${ }^{\star} \mathrm{C}=$ Control, $\mathrm{A}=$ treatment with monosodium glutamate at $5000 \mathrm{ppm}$, $B=$ treatment with partially purified glutaminase $(6.0 \mathrm{U} / 100 \mathrm{~g})$.

** Means followed by different superscripts (within each column) and different subscripts (within each row are significantly different $(p \leq 0.05)$.

Table 5. Psychrotrophic count (cfu/g) in beef burgers during frozen storage at $-18^{\circ} \mathrm{C}$ for 3 months.

\begin{tabular}{c|c|c|c|c|}
\hline \multirow{2}{*}{ Treatments } & \multicolumn{4}{|c|}{ Storage time (month) } \\
\cline { 2 - 5 } & Zero & 1 & 2 & 3 \\
\hline${ }^{*}$ C & ${ }^{*} 1.6 \times 10^{2 a}{ }_{\mathrm{d}}$ & $2.1 \times 10^{2 \mathrm{a}}{ }_{\mathrm{c}}$ & $2.5 \times 10^{2 \mathrm{a}}$ & $3.7 \times 10^{2 \mathrm{a}}$ \\
\hline $\mathrm{A}$ & $\star * *<10$ & $<10$ & $<10$ & $<10$ \\
\hline B & $<10$ & $1.8 \times 10^{2 \mathrm{a}}{ }_{\mathrm{c}}$ & $2.2 \times 10^{2 \mathrm{a}}$ & $3.5 \times 10^{2 \mathrm{a}}{ }_{\mathrm{a}}$ \\
\hline
\end{tabular}

${ }^{*} \mathrm{C}=$ Control, $\mathrm{A}=$ treatment with monosodium glutamate at $5000 \mathrm{ppm}$, $B=$ treatment with partially purified glutaminase $(6.0 \mathrm{U} / 100 \mathrm{~g})$.

** Means followed by different superscripts (within each column) and different subscripts (within row) are significantly different $(p \leq 0.05)$.

${ }^{* * *}$ Estimated Standard Plate Count (ESPC/g).

Counts in the control and treatment B show a similar trend, where a slight increase in the psychrotrophic count was noted during storage and did not exceed $10^{2} \mathrm{cfu} / \mathrm{g}$. On the other hand, samples A showed no growth at all and this was probably due to the inhibiting effect of monosodium glutamate [40]. Similarly, a slight but significant increase, in the mold and yeast count was observed during storage with no significant differences between control and sample B. Sample A showed lower counts and this was probably due to the inhibitory effect of monosodium glutamate $[40,41]$ and in all cases numbers did not exceed $3.6 \times 10^{3} \mathrm{cfu} / \mathrm{g}$, which is very acceptable. The Egyptian Standard (ES: 1688-2005) [14] for frozen beef burgers indicates that the coliform group count should not exceed $10^{2} \mathrm{cfu} / \mathrm{g}$. However, there was no evidence of the presence of the coliform group in any treatment as well as the control.

\section{Sensory evaluation of beef burgers}

The results for sensory evaluation of beef burgers after three months of storage are presented in Table 6. Most of beef burger characteristics have been affected by the enzymatic treatment (B). The highest odor, texture and taste scores $(8.9,8.9$ and 8.5 , respectively) were recorded for treatment B. Meanwhile, the lowest color score (7.0) was given by the panelists for treatment $\mathrm{B}$; the color score decreased due to the increment in the undesirable dark color, which was probably due to the formation of the Maillard reaction between reducing sugars and the formed amino acids. Also, the highest overall quality score (8.6) was for treatment B. Therefore, it can be concluded that, the partially purified glutaminase improved the overall quality of frozen beef burgers especially, the enhancement in odor and taste.

Table 6. Sensory evaluation of beef burgers at the end of 3 month of frozen storage at $-18^{\circ} \mathrm{C}( \pm \mathrm{SD})$.

\begin{tabular}{|c|c|c|c|}
\hline \multicolumn{4}{|c|}{ Characteristics Treatments } \\
\hline & ${ }^{\star} \mathrm{C}$ & A & B \\
\hline Odor & $* * 7.0^{c} \pm 0.01$ & $7.5^{\mathrm{b}} \pm 0.00$ & $8.9^{a} \pm 0.02$ \\
\hline Color & $8.8^{\mathrm{a}} \pm 0.00$ & $8.7^{\mathrm{a}} \pm 0.00$ & $7.0^{b} \pm 0.01$ \\
\hline Texture & $7.9^{b} \pm 0.02$ & $8.1^{b} \pm 0.01$ & $8.9^{\mathrm{a}} \pm 0.00$ \\
\hline Taste & $6.5^{c} \pm 0.00$ & $7.7^{b} \pm 0.02$ & $8.5^{\mathrm{a}} \pm 0.01$ \\
\hline Overall quality & $7.3^{c} \pm 0.03$ & $7.9^{b} \pm 0.02$ & $8.6^{\mathrm{a}} \pm 0.00$ \\
\hline
\end{tabular}

\section{Conclusion}

The extracellular L-glutaminase of Aspergillus oryzae NRRL 32567 was successfully utilized as a flavor enhancing agent in beef burgers. The produced burgers showed high sensory scores as well as high microbiological quality. As a result, L-glutamiase from this source could be considered as a potential flavor improver in food industries replacing monosodium glutamate. However more applications on other products should be also tested.

\section{REFERENCES}

1. lyer, P., Singhal, R. S. (2009). Screening and selection of marine isolate for L-glutaminase production and media optimization using response surface methodology. Applied Biochemistry and Biotechnology, 159(1), 233-250. https://doi.org/10.1007/ s12010-008-8522-7

2. Orabi, H.M., El-Fakharany, E.M., Abdelkhalek, E.S., Sidkey, N.M. (2019). L-asparaginase and I-glutaminase: sources, production, and applications in medicine and industry. Journal of Microbiolgy Biotechnology Food Sciences, 9(2), 179-190. https://doi. org/10.15414/jmbfs.2019.9.2.179-190
3. Chou, C. C., Yu, R. -C., Tsai, C. T. (1993). Production of glutaminase by Actinomucor elegans, Actinomucor taiwanensis and Aspergillus oryzae. Journal Chinese Agricultural Chemical Society, 31, 78-78.

4. Chou, C.C., Hwan, C.-H. (1994). Effect of ethanol on the hydrolysis of protein and lipid during the ageing of a Chinese fermented soya bean curd-Sufu. Journal of the Science of Food and Agriculture, 66(3), 393-398. https://doi.org/10.1002/jsfa.2740660318 5. Lu, L. -M., Yu, R. -C., Chou, C. C. (1996). Purification and some properties of glutaminase from Actinomucor taiwan- 
ensis, starter of sufu. Journal of the Science of Food and Agriculture, 70(4), 509-514. https://doi.org/10.1002/(sici)1097-0010(199604)70:4<509:: aid-jsfa532>3.0.c0;2-7

6. Binod, P., Sindhu, R., Madhavan, A., Abraham, A., Mathew, A.K., Beevi, U.S. et al. (2017). Recent developments in L- glutaminase production and applications - An overview. Bioresource Technology, 245, 1766-1774. https://doi.org/10.1016/j. biortech.2017.05.059

7. Barzkar, N., Sohail, M., Jahromi Tamadoni, S., Nahavandi, R., Khodadadi, M/ (2021). Marine microbial L-glutaminase: from pharmaceutical to food industry. Applied Microbiology and Biotechnology, 105(11), 4453-4466. https://doi.org/10.1007/ s00253-021-11356-1

8. Farombi, E. O., Onyema, O. O. (2006). Monosodium glutamate-induced oxidative damage and genotoxicity in the rat: Modulatory role of vitamin C, vitamin E and quercetin. $\mathrm{Hu}$ man and Experimental Toxicology, 25(5), 251-259. https://doi. org/10.1191/0960327106ht6210a

9. Banerjee, A., Mukherjee, S., Maji, B.K. (2021). Worldwide flavor enhancer monosodium glutamate combined with high lipid diet provokes metabolic alterations and systemic anomalies: An overview. Toxicology Reports, 8, 938-961. https://doi. org/10.1016/j.toxrep.2021.04.009

10. Nandakumar, R., Yoshimune, K., Wakayama, M., Moriguchi, M. (2003). Microbial glutaminase: biochemistry, molecular approaches and applications in the food industry. Journal of Molecular Catalysis B: Enzymatic, 23(2-6), 87-100. https://doi. org/10.1016/s1381-1177(03)00075-4

11. Amobonye, A., Singh, S., Pillai, S. (2019). Recent advances in microbial glutaminase production and applications - a concise review. Critical reviews in biotechnology, 39(7), 944-963. https://doi.org/10.1080/07388551.2019.1640659

12. Alian, A. M., Bazaraa, W. A., El- Shimi, N. M., Mohamed, R. M. (2015). Optimization of L-glutaminase synthesis by Aspergillus oryzae NRRL 32657 in submerged culture. African Journal of Microbiology Research, 9(9), 588-597. https://doi.org/10.5897/ ajmr2014.7317

13. Bazaraa, W., Alian, A., El-Shimi, N., Mohamed, R. (2016). Purification and characterization of extracellular glutaminase from Aspergillus oryzae NRRL 32567. Biocatalysis and Agricultural Biotechnology, 6, 76-81. https://doi.org/10.1016/j. bcab.2016.02.009

14. Egyptian Standard Specification (2005). Frozen beef burger. Egyptian Organization for Standardization and Quality Control, Ministry of Industry and Trade. Egypt, No 1688-2005.

15. Imada, A., Igarasi, S., Nakahama, K., Isono, M. (1973). Asparaginase and glutaminase activities of microorganisms. Journal of General Microbiology, 76(1), 85-99. https://doi. org/10.1099/00221287-76-1-85

16. A.O.A.C. (2005). Official Methods of Analysis of AOAC International, $18^{\text {th }}$ ed. Gaithersburg, Maryland 20877-2417, USA.

17. Virgili, M., Monti, B., Lorusso, A., Bentivogli, M., Contestabile, A. (1999). Developmental effects of in vivo and in vitro inhibition of nitric oxide synthase in neurons. Brain Research, 839(2), 164-172. https://doi.org/10.1016/s00068993(99)01750-3

18. Trindade, R. A., Mancini-Filho, J., Villavicencio, A. L. C. H. (2010). Natural antioxidants protecting irradiated beef burgers from lipid oxidation. LWT - Food Science and Technology, 43(1), 98-104. https://doi.org/10.1016/j.lwt.2009.06.013

19. Cousin, M. A. M., Vasavada, P. C. (1992). Psychrotrophic microorganisms. Chapter in a book: Compendium of methods for the microbiological examination of foods. $3^{\text {rd }}$ Ed. American Public Health Association Washington. D. C.

20. Berry, B.W. (1992). Low fat level effects on sensory cooking and chemical properties of ground beef patties. Journal of Food Science, 57(3), 537-542. https://doi. org/10.1111/j.1365-2621.1992.tb08037.x

21. Rao, M., Blane, K. (1985). PC-STAT, Statistical Programs for Microcomputers. Version 1A. Department of Food Science and Technology, The University of Georgia, Athens, GA.

22. Gehan Kassam, M. A., Emara, M. M. T. (2010). Quality and acceptability of value-added beef burger. World Journal of Dairy and Food Sciences, 5(1), 14-20.
23. Kassem, G. M., Atta-Alla, O. A., Ali, F. H. M. (2011). Improving the quality of beef burger by adding thyme essential oil and jojoba oil. Archivos de Zootecnia, 60(231), 787-795. https://doi. org/10.4321/s0004-05922011000300066

24. Akwetey, W., Knipe, C. L. (2012). Sensory attributes and texture profile of beef burgers with gari. Meat Science, 92(4), 745748. https://doi.org/10.1016/j.meatsci.2012.06.032

25. Mohamed, R. M. (2015). Microbial production of L-glutaminase and its use as a flavor enhancer. Ph.D thesis. Department of Food Science, Faculty of Agriculture Cairo University.

26. Alakali, J. S., Irtwange, S. V., Mzer, M. T. (2010). Quality evaluation of beef patties formulated with bambara groundnut (Vigna subterranean L.) seed flour. Meat Science, 85(2), 215-223. https://doi.org/10.1016/j.meatsci.2009.12.027

27. Aleson-Carbonella, L., Fernández-Lópeza, J., Pérez-Alvareza, J.A., Kuri, V. (2005). Characteristics of beef burger as influenced by various types of lemon albedo. Innovative Food Science and Emerging Technologies, 6(2), 247-255. https://doi. org/10.1016/j.ifset.2005.01.002

28. Reihani, S. F. S., Tan, -T., Huda, N., Easa, A. M. (2014). Frozen storage stability of beef patties incorporated with extracts from ulam raja leaves (Cosmos caudatus). Food Chemistry, 155, 1723. https://doi.org/10.1016/j.foodchem.2014.01.027

29. Molly, K., Demeyer, D., Johansson, G., Raemaekers, M., Ghistelinck, M., Geenen, I. (1997). The importance of meat enzymes in ripening and flavour generation in dry fermented sausages. First results of a European project. Food Chemistry, 59(4), 539-545. https://doi.org/10.1016/s0308-8146(97)00004-6 30. Hughes, M. C., Kerry, J. P., Arendt, E. K., Kenneally, P. M., McSweeney, P. L. H., O'Neill, E. E. (2002). Characterization of proteolysis during the ripening of semi-dry fermented sausages. Meat Science, 62(2), 205-216. https://doi.org/10.1016/s03091740(01)00248-0

31. Agyei, D. (2015). Bioactive proteins and peptides from soybeans. Recent Patents on Food, Nutrition and Agriculture, 7(2), 100-107. https://doi.org/10.2174/221279840766615062913 4141

32. MacLeod, G. (1994). The flavour of beef. Chapter in a book: Flavor of meat and meat products. Glasgow, UK: Blackie Academic and Professional, 1994.

33. Görgüç, A., Gençdağ, E., Yılmaz, F. M. (2020). Bioactive peptides derived from plant origin byproducts: Biological activities and techno-functional utilizations in food developments A review. Food Research International, 136, Article 109504. https://doi.org/10.1016/j.foodres.2020.109504

34. Durá, M. A., Flores, M., Toldrá, F. M. (2004). Effect of Debaryomyces spp. on the proteolysis of dry-fermented sausages. Meat Science, 68(2), 319-328. https://doi.org/10.1016/j.meatsci.2004.03.015

35. Maga, J. A. (1998). Umami flavour of meat. Chapter in a book: Flavor of meat, meat products and seafoods, $2^{\text {nd }}$ Ed. London, UK: Blackie Academic and Professional, 1998.

36. Toldrá, F., Sanz, Y., Flores, M. (2001). Meat fermentation technology. Chapter in a book: Meat science and Applications. Marcel Dekker, Inc. New York, 2001.

37. Liu, B. -Y., Zhu, K. -X., Guo, X. -N., Peng, W., Zhou, H. -M. (2017). Effect of deamidation-induced modification on umami and bitter taste of wheat gluten hydrolysates. Journal of the Science of Food and Agriculture, 97(10), 3181-3188. https://doi.org/10.1002/ jsfa.8162

38. Georgantelis, D., Blekas, G., Katikou, P., Ambrosiadis, I. Fletouris, D. J. (2007). Effect of rosemary extract, chitosan and $\alpha$-tocopherol on lipid oxidation and colour stability during frozen storage of beef burgers. Meat Science, 75(2), 256-264 https://doi.org/10.1016/j.meatsci.2006.07.018

39. Turhan, S., Sagir, I., Sule Ustun, N. (2005). Utilization of hazelnut pellicle in low-fat beef burgers. Meat Science, 71(2), 312316. https://doi.org/10.1016/j.meatsci.2005.03.027

40. Jinap, S., Hajeb, P. (2010). Glutamate. Its applications in food and contribution to health. Appetite, 55(1), 1-10. https://doi. org/10.1016/j.appet.2010.05.002

41. Löliger, J. (2000). Function and importance of glutamate for savory foods. The Journal of Nutrition, 130(4SUPPL.), 915S-920S. https://doi.org/10.1093/jn/130.4.915s 


\section{AUTHOR INFORMATION}

Reda M. Mohamed, PhD, Lecturer, Department of Food Science, Faculty of Agriculture, Cairo University. Gamaa Street, Giza, 12613, Egypt. Tel.: +2-115-659-47-47, E-mail: reda_karrim@yahoo.com ORCID: https://orcid.org/0000-0001-5817-9187

Wael A. Bazaraa, Professor, Department of Food Science, Faculty of Agriculture, Cairo University. Gamaa Street, Giza, 12613, Egypt. Tel.: +2-0100-415-49-49, E-mail: waelbazaraa@agr.cu.edu.eg

ORCID: https://orcid.org/0000-0003-4696-9848

* corresponding author

Ahmed M. Alian, Emeritus Professor, Department of Food Science, Faculty of Agriculture, Cairo University. Gamaa Street, Giza, 12613, Egypt. Tel.: +2-122-362-31-40, E-mail: dr.alian@hotmail.com

Nagwa M. El-Shimi, Emeritus Professor, Department of Food Science, Faculty of Agriculture, Cairo University. Gamaa Street, Giza, 12613, Egypt. (Passed away)

All authors bear responsibility for the work and presented data.

All authors made an equal contribution to the work.

The authors Mohamed R. M., Bazaraa W. A. and Alian A. M. were equally involved in writing the manuscript and bear the equal responsibility for plagiarism.

The authors declare no conflict of interest. 